\title{
MR. CROLL ON THE DISPERSION OF BOULDERS.
}

SIR,-It is with reluctance that I crave space for a few remarks on Mr. Croll's article, but I think it desirable that some of the diffienlties with which his theory seems to be beset should be stated without unnecessary delay.

Difficulties connected with Physical Geography.-The ground W.S.W. of Wasdale Crag does not rise to a sufficient height to have enabled it to generate or give a direction to an iee-stream capable of carrying blocks from Wasdale Crag over the Pennine chain. In the case of an ice-stream assailing the Lake District from an external source, the questions arise-How was it propelled across the ridges and valleys intervening between the Irish Sea and Wasdale Crag? Where was the originating high ground situated? Or, if the stream came from a Polar ice-cap in a southerly direction, how was it diverted towards the E.N.E.? These difficulties Mr. Croll may be able to explain, but I cannot see how his theory can be reconciled with the following facts.

Prevailing Direction of Glasiation.-As Mr. Croll surmises, many instances of glaciated rock-surfaces showing the passage of ice across the $N$. of England in an E.N.E. direction may possibly yet be found at high levels, but the fact onght not to be oxerlooked that most of the high-level instances hitherto discovered do not trend in the above direction, but nearly at right angles to it, or in approximately opposite directions (instances-Gaythorn Tileworks, N. and S.; watershed between Kentmere and Long Sleddale, N. and $S_{\text {. }}{ }^{1}$ many roches montonnées north-east of Windermere, glaciated from N.N.W.; Coniston Old Man, near Copper Works, N. and N.N.W.; south of Pudding Cove, nearly N.; entrance of Low Water Cwm, glaciated from between E. and N.E., at a beight of nearly 2,000 feet above the sea). At lower levels, between Kentmere and the Irish Sea, the glaciation in nearly every instance $I$ hare yet seen has come from points of the compass between $N$. and N.W. (see article, Grol. MAa. for October, 1870); in a very few instances from between N. and E.N.E., rather than tovoards these points. What seems to be the original glaciation, indicated by small parallel undulations, has generally come from between $N$. and N.N.W., instead of trending in the direction of Mr. Croll's supposed ice-sheet.

Direction of Drift-carriage.-Between Wasdale Crag and the Pennine chain, the direction in which the drift has been carried varies from N. round by $E$. to $S$., though the part of the drift which found its way over Stainmoor travelled E.N.E. Between Wasdale Crag and the Irish See, the direction is generally from N. to $S$., or from points between N.W. and N.E. In many instances the drift-carriage has crossed the strix at greater or less angles. The Eskdale granitic drift, in a matrix of Boulder-clay, crosses the most splendid specimen of glaciated rock-surface $I$ have yet anywhere seen. On the coast adjacent to Blackcombe, the granite, from the $\mathrm{N}$., is found in the three drifts (lower Boulder-clay, middle sand, and upper Boulder-clay), and these three drifts would appear to represent the main part of the glacial period in the Lake Distriet, so as. to render it highly improbable that any land ice-stream from the Irish Sea could ever have flowed E.N.E. to Wasdale Crag. On the supposition that the Eskdale drift, and the nearly parallel Criffell drift, ${ }^{2}$ were carried by a stream of land-ice, the channel of the Irish Sea must have been partly or wholly filled up to a great height by this stream, as Mr. Eccleston has found blocks of Eskdale-fell granite more than 1,000 feet above the sea on the west side of Blackcombe, and this stream must have carried the granite as far south at least as Bridgenorth and Wolverhampton. On the Pennine bills, and in the Yorkshire valleys, south of the latitude of Wasdale Crag, the drift-carriage has either approximately followed the ralleys, or come chiefly from the N.W. or N.N.W., ${ }^{3}$ if we except chalk-flints, whieh may possibly have come from Ireland. Fragments of Wasdale Crag granite are found in the brown Boulder-clay west of Ripon, and, according to Mr. Green, F.G.S., a boulder of this granite may be seen at Royston, near Barnsley.

Connection between the Direction of Drift-carriage and Altitzede.-Though the Granite in the Wasdale area rises to a height of about 1,600 feet above the sea on

1 Mr. Rutley has fond strim near Skeggles Water, ranning nearly E. and W. (Groc. MAG.

for December, 1870). Criffell granite as far at least of ponrn (near Penrith), and nearly the whole way uphill, or in

opposition to the drainage of thes ofintry.
On the north side of Rombald's Moor, however, Millstone-grit thas been beautifully smoothed and striated. $W_{6}$ and $E$. at a height of about 900 feet above the sea. 
high ground separated from Wasdale Crag by a watershed, Wasdale Crag (or rather Wasdale hill, from which, I believe, most of the boulders were dispersed, is only 1,479 feet above the sea-level. An ice-stream, such as that supposed by Mr. Croll, with a surface low enough to have received fallen blocks of granite, could scarcely have been 100 feet thick on Stainmoor pass. Could such a thin layer of ice bave persisted in moving over the pass, so as to keep the ice-stream on the other side supplied with blocks? and in what way did the eastern ice-stream receive or acquire a motion sufficient to enable it to ignore not only minor or subordinate ridges, but hills in E. Yorkshire more than 1,000 feet in height? 1 If we suppose Mr. Croll's ice-stream to have pushed the blocks from Wasdale Orag along its bed (a theory which, of the two, would best accord with the fact that many of the blocks are more or less rounded, and often imbedded in drift), the question arises, how could the supposed ice-stream have acquired a power of shoving so many large boulders up a steep slope nearly 1,000 feet in vertical height? 2

Dispersion in different Directions.-Mr. Croll has justly remarked that ice-streams may have varied their directions as their surfaces stood at different levels; but a stream of land-ice impinging on Wasdale Crag at a level which would have given it a direction towards Tebay would certainly have sent it along the valley of the Lune, in which valley no blooks of granite have been found. No one, I suppose, would presume that a local ice-stream could have flowed up this valley so as to check the glacier from Wasdale Cray. The existing configuration of the ground is likewise inconsistent with the idea of local ice-streams flowing north and north-east from Wasdale Crag. But the main difficulty in the way of accepting Mr. Croll's theory is to be found in the fact that Wasdale Crag boulders have been carried south in the direction of Kendal over a pass traversed by the Kendal road, which approaches Stainmoor pass in altitude. To the north of Kendal they are found in considerable numbers, imbedded in drift as well as appearing at the surface. During what stage in the lowering of the 2,000 feet ice-sheet were these boulders carried southwards?

Mr. Croll seems to think that radiating dispersion can be more easily explained by land-ice than by floating-ice. That land-ice could have dispersed boulders in various and often opposite directions from detached or semi-detached hills of moderate elevation appears to me almost impossible. The advantages possessed by the floating sea-ice (not iceberg) theory, over the land-ice theory, consist in the fact, that coast-ice may be dispersed by variously-directed winds blowing off the land; by drift-currents arising from these winds; and by ebb-tidal currents. Through these mediums it may find its way into the courses of great tidal and other currents, and these may change their directions with changes in the form of the shore or sea-bottom, produced by the sinking or rising of the land, and by denudation.

\section{Mackintosh.}

\section{THE BLUE CLAY IN THE WEST OF ENGLAND.}

Sre,-Allow me through your pages to convey to $\mathrm{Mr}$. De Rance my sincere regret for having erroneously attributed the authorship of his paper "On the Glacial Phenomena of Lancashire and Cheshire," to Prof. Hull. I never met with the paper in full, and therefore avoided quoting its views. With regard to the thickness of the blue clay near Llandudno, the reference is to a paper in your November number, by Mr. H. F. Hall (not Mr. Hull, as by a misprint it appears in your correspondent's letter). My impression, on reading the statement, was that it was excessive, but $I$ would not

\footnotetext{
1 The land-ice theory is rendered still more improbable by the facts, that Wasdale Crag granite has fonnd its way as far as the mouth of the Humber; that from a narrow neck on Stainmoor it has expanded over an area forty miles in breadth (from Ripon and York to the sea-coast); and that Liassic drift from the N. Yorkshire hills (over which the granite must have passed) has been dispersed over the plain of York. Gryphoea incurva have been found in Boulder-clay as far west as Keighley.

Blocks of Permian breccia have been moved up a neighbouring slope to a vertical extent of 1,000 feet, and this, I think, can be sufficiently explained by the progressively upward movement of coast-ice during a subsidence of the land.
} 